\title{
Albania's Monetary Policy and the Basic Indicators that Effect the Economic Growth
}

\author{
Phd. Cand. Bernard Balla
}

\begin{abstract}
Macroeconomic policies aim to stabilize the economy by achieving their goal of price stability, full employment and economic growth. Price stability is the responsibility of macroeconomic policies that are developed to maintain a low inflation rate, contribute to the solidity of the domestic product and maintain an exchange rate that can be predictable. The purpose of this paper is to analyze Albania's monetary policy by highlighting the main indicators that can be used as a measurement of the efficiency of this policy in the economic development. The literature review shows that there are many attitudes regarding the factors that need to be taken into consideration when analyzing monetary policies, including the elements of fiscal policies. In the Albanian economy, the prices and the level of inflation are the most important aspects. The Bank of Albania uses the inflation targeting regime, considering that the main indicator of inflationary pressures in the economy is the deviation of inflation forecasted in the medium term by its target level. In numerical terms, the bank intends to maintain its annual growth in consumer prices at the level of 3\%. According to the latest reports published by the Bank of Albania in 2019, monetary policy continues to contribute positively to a financial environment with a low interest rate and an annual inflation rate of $2 \%$. Although the inflation rate hit the lowest value of $1.8 \%$ in 2018, a balanced rate was achieved through the reduction of interest rates and risk premiums in financial markets and, more recently, through the tightening of the exchange rate. These monetary conditions are appropriate to support the growth of domestic demand and the strengthening of inflationary pressures.
\end{abstract}

Keywords: Macroeconomics, Monetary policy, Inflation, Prices, Economic development

\section{Introduction}

Banks and their activity are one of the main pillars on which the modern country stability relies on. During the last three decades, Albanian's economy has undergone different and major changes. Considering the political changes at the beginning of the ' 90 s, the lack of experience of the Albanian market in the international area, not having a structured bank system, the impact of the global crisis in a new private economy -and more- have played a significant role of how the economy has taken its current state. It is important to analyze the role and effectiveness of the central bank in this situation as it is directly connected to the monetary policy. In order to have a stable bank system and reliable monetary policy, the inflation rates should remain low and balanced. A key test to determine if a central bank has undertaken the right monetary policies is the level of 


\section{Journal of International Cooperation and Development}

www.richtmann.org/journal

Vol 2, No 2, November 2019

trust its citizens have put on their investments or savings, and as a result, on interest rates. The objective of this paper is to analyze the Albania's monetary policy by highlighting the main indicators that can be used as a measurement of the efficiency of this policy in the economic development. There is a major agreement of the role of economic policy: stable prices, employment growth, and economic growth. To achieve these goals, several instruments are used, and mainly in this paper, the focus will be Monetary Policy. It is essential to understand its role, how can it contribute effectively in economic growth, and how should it be conducted to provide the desired effects.

\section{Methodology}

This paper makes an analysis of the monetary policy through literature review and through statistical analysis on data in Albania. The analysis is conducted responding to the "why" and "how" the bank of Albania has used certain monetary policy. To discuss the effect of monetary policy in economic growth, the inflation rate has been used to represent the monetary policy and the the GDP rate to measure the economic growth. The analysis is based on data from 2011-2018.

\section{Literature Review}

The monetary policy is broadly used as a mean to control the money supply by the national banks. Its effect in financial markets affects the macroeconomy environment in a state (Gust and López-Salido, 2014). For decades the debate over the influence of monetary policy on economic growth has raised discussing whether the monetary policy can stimulate or stabilize the general state of the economy in a country. There is an agreement between the analysts that the monetary policy can actually influence the inflation rate but regarding the effect on real economic activities there are three ideologies:

1. The Keynesian point of view says that the monetary policy effects the inflation, the investments, the production, the level of employment and the real income. The lack of stability comes from different factors and from various norms of decision-makers. Despite divergences, all Keynesian economists agree on the effect of monetary policy in the economy at least in the short run. The disturbances of the demand are the one that causes economic fluctuations and they believe that the demand can be managed by the monetary policy (de Long and Summers 1988).

2. The second ideology agrees with the effect of the monetary policy in the short run but the lags and magnitudes cannot be measured, while in the long run affects only the nominal variables.

3. The third ideology includes classical economics that has a focus on the full 


\section{Journal of International Cooperation and Development}

www.richtmann.org/journal

Vol 2, No 2, November 2019

employment equilibrium. Classical economists think that the economy can only be shocked by unexpected monetary policy shocks and not by the agents that take decisions regarding monetary politics (Lucas 1972).

Monetary policies in modern literature, emphasizes the role that the central banks play in maintaining price stability and financial stability (Stein et al., 2011). Studies of monetary policies have evolved with the desire to bring monetary economics closer to central bank activities. A central bank operating in a modern banking system typically has several different tools at its disposal for affecting private economic and financial behavior. In general, these include the ability to determine what reserves banks and other depository institutions must hold in relation to their deposits, to vary the supply of such reserves by buying and selling (government) securities for the central bank's own account, to lend reserves directly to banks, to set minimum conditions for particular kinds of credit transactions, and to regulate a variety of aspects of ordinary banking and other financial activities. As Friedman emphasized, between these several devices, the buying, and selling of securities, or open market operations, is typically the primary focus of the monetary policy (B. M. Friedman, 1988). Open market operations are basically a trading activity, and the instrument used by a central bank to buy or sell securities may be by price or quantity. This way, buying and selling to the traders in the market with a specific price, the central bank allows 'the market' to determine the price and respective quantity of that reserve to be held.

The supporters of Keynesianism suggested that an economy doesn't operate in its full potential, and so, internal instruments should be used by countries to keep the employment rates high at certain times. In this context, effective monetary and fiscal policies should be undertaken to help the economy being close to their full potential. As mentioned also by Woodford (2002), in summary, some tools to implement monetary policies may include:

- Tweaking interest rates, which impacts the liquidity of money in an economy;

- Reserve requirements, which indicate banks to maintain a higher or lower amount of their deposits as reserves and the rest available for loans;

- Open Market Operations, also mentioned earlier in this study, involves buying and selling of government securities, like bonds or foreign currencies, in the open market (Woodford, 2002).

Finding balance in a dynamic global market is not an easy task. As also mentioned by Friedman about the early theory of Monetary Policy of Keynes, the latter offered an explanation for the presumed impotence of monetary policy to stem the depression, and if liquidity preference is absolute or nearly so -as Keynes believed likely in times of high unemployment-interest rates cannot be lowered by monetary measures. If investment and consumption are little affected by interest rate, then even lower interest rates, if they could be achieved, would do little good (M. Friedman, 1968).

Finally, considering the dynamics of globalization and the impact of the 


\section{Journal of International Cooperation and Development}

www.richtmann.org/journal

Vol 2, No 2, November 2019

international market in today's economy, countries find it more difficult to implement long-term successful monetary policies. They can contribute to offsetting major disturbances in the economic system and help hold in check independent secular exhilaration by a slower rate of monetary growth than would be desirable otherwise. But, in general, it is agreed that monetary policies are mostly used to smooth short term impacts, and forecast future policies to be undertaken only when a clear danger or opportunity arises.

\section{Monetary Policy in Albania}

According to Law 8269/1997 "On the Bank of Albania", as amended, the Bank of Albania's main monetary policy objective is to achieve and maintain price stability. (Constitution of the Republic of Albania, 1997)

With price stability, the Bank of Albania will understand the maintenance of consumer price inflation at 3.0 percent in the medium term. Monetary policy, maintaining at certain levels inflation fluctuations, improves the distribution of resources efficiently and thus increasing the overall welfare of the economy. Also, a low level and stable inflation rate, helps the banking system development and increases the financial system's sustainability.

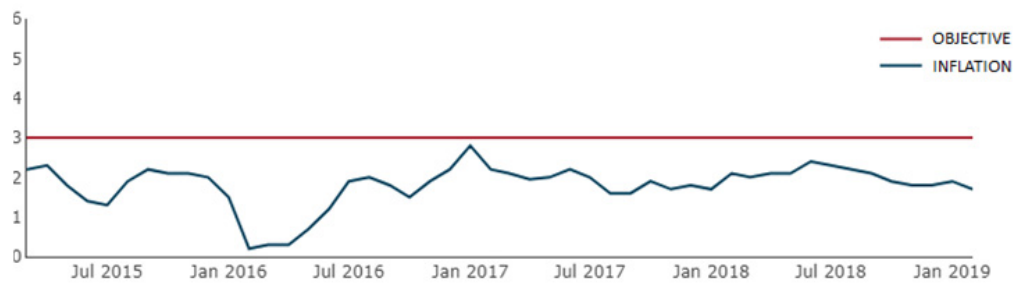

Figure 1: The objective and real inflation.

Source: Bank of Albania

In this way, this price stability gives a direct contribution to the long-term economic growth of the country. A number of unforeseen factors, outside the influence of monetary policy, affect inflation, so it is constantly fluctuating from the target. However, the monetary policy aims that the inflation rate of consumer prices in the albanian economy in average terms and for long periods of time to be $3.0 \%$.

An inflation is in line with the development stage of the Albanian economy, as a small economy, and a low inflation rate helps preserve positive real interest rates and maintain the stability of the banking system. The inflation target indicates the goal of controlling price increases at a level close to that of the European Central Bank, which 


\section{Journal of International Cooperation and Development}

www.richtmann.org/journal

Vol 2, No 2, November 2019

has an inflation target below level 2. The objective level enables achieving real convergence and nominal value of the albanian economy with the economies of the European Union in the medium term.

\subsection{Bank of Albania monetary policy instrument}

Up to the end of the year 2000, the Bank of Albania was conducting a direct instrument policy through two administrative decisions:

1) setting limits to the growth of outstanding credit of commercial banks; and

2) Setting an obligation for the banks that had the state as an owner as well as the banks where the state had a share of capital to keep the minimum level of interest rates set by the Bank of Albania for time deposits in Lek currency.

As the financial market was not responding any more to these constraints, Bank of Albania changed the course of action and decided to implement the monetary policy through the use of the market instruments. (Bank of Albania)

The implementation of monetary policy is realized through a series of indirect monetary instruments as following:

- Open Market Operations

Open Market Operations are classified into three other subcategories depending on the purpose of their use: the main market, regulatory and structural operation. According to the Bank of Albania, repurchase and reverse repurchase agreements are used as the main and regulatory operation, while outright sales are used only in structural operations. Repurchase agreements aim to reduce the liquidity in the banking system whereby the Bank of Albania sells securities with the right to repurchase it. Reverse Repurchase Agreements are open market operations aiming the temporary increase of liquidity in the banking system.

The Bank of Albania repurchases (reverse) agreements with a maturity of seven days as the main instrument for implementing monetary policy. This instrument aims at short-term liquidity management of the banking system, with the intention to stabilize the market interest rates. Determining the interest rate of these one-week maturity instruments determines the monetary policy position.

Meanwhile, as regulatory market operations (market fluctuations) are used Repurchase and reverse repurchase agreements with maturities of one day, one month and three months.

The Bank of Albania classifies as open market structural operations outright sales that have a permanent effect on the money market.

- Standing facilities

Permanent facilities are instruments that help the banks overcome temporary liquidity problems by investing excess liquidity through a one-day deposit or borrowing through a one day loan. These instruments are realized exclusively 


\section{Journal of International Cooperation and Development}

www.richtmann.org/journal

Vol 2, No 2, November 2019

and always with the initiative of the banks to supply and take in overnight liquidity by the Bank of Albania.

- Minimum Reverse requirement

The obligatory reserve represents the funds that the banks have to hold in the Bank of Albania in Lek and other currencies. For a long time the minimum revere has been 10 per cent while starting from 24 July 2018, reserve rates have escalated by increasing the reserve requirement rate in foreign currency. The required reserve ratio in LEK currency is 7.5 per cent for liabilities with a maturity not longer than 12 months and 5.0 percent for liabilities with an initial term of more than 12 months to 2 years. The required reserve rate in foreign currency is 12.5 percent for foreign currency liabilities when these account for less than 50 percent of the total and 20 per cent for the portion of foreign currency liabilities over $50 \%$ of the total.

The realization of the monetary policy aims:

- "Effectively sizing the liquidity deficit of the banking system;

- Forecasting the liquidity needs of the banking system;

- Executing the open market operations." (Bank of Albania)

\subsection{Factors that influence monetary policy effectiveness in Albania}

Below are listed a number of factors that affect the effectiveness of monetary policy and orientate its actions:

1. The high level of use of the EUR currency

The high level of euro use in the economy directly affects the reduction of the monetary policy effectiveness. As economic entities are more sensitive to exchange rate fluctuations, the free exchange rate does not act as a stabilizing element. Fiscal policies are also affected by the potential rise in the cost of debt in the foreign currency. The effects extend to the exposure of the financial system and to the central bank, which is affected by the maintenance of a high level of foreign exchange reserves. In order to increase the use of the domestic currency, a Memorandum of Cooperation was drafted, whereby the Bank of Albania, the Ministry of Finance and the Financial Supervisory Authority have to undertake all appropriate actions during the "de-euroziaton" process.

Some of the actions taken are:

a. Differentiation and increase of the reserve requirement rate for foreign currencies liabilities. The increase of the reserve rate in foreign currency makes the deposit more expensive for banks. Thus, to offset the additional costs, banks must lower the interest payable for savings in the euro or to increase the interest rates on loans in that currency so that this products will become less attractive. 


\section{Journal of International Cooperation and Development}

www.richtmann.org/journal

Vol 2, No 2, November 2019

b. The increase in the minimum regulatory requirement for the value of liquid assets in foreign currency. In particular, liquid assets in foreign currency will be required to be not less than $20 \%$ of short-term liabilities in foreign currency (was 15\%), while for liquid assets in lek currency, the ratio level will be maintained at $15 \%$;

c. Informing the borrowers regarding the risks associated with foreign currency borrowing. The banks are required to propose to the borrower an alternative credit in Lek currency.

d. The aim of the "de- euroziation package" is to increase the use of the national currency and generate a gradual and harmonic reduction of foreign currency use in the economy.

2. Time of monetary policy transmission

The chosen monetary policy is always oriented from the future by predicting the expected inflation. Due to the reaction of financial markets, which is not always immediate, or the expectations of the main economic actors against interest rates and liquidity in the economy, the monetary policy transmission mechanism can go from one to three years. Thus, the effects of the policy monetary developments appear in the economy with delay. For this reason, the central bank analyzes information and forecasts in order to orient the monetary policy.

3. Development in the external sector

4. High level of non-performing loans- trends in lending

The banking sector is following a very cautious policy regarding lending based on the problems faced in particular sectors of the economy and the dictating policies of the parent banks.

\section{Connection between Inflation and GDP}

The data for the statistical analysis were taken from the bank of Albania and INSTAT and they show the inflation rate and the GDP in Albania for the period 2011-2018.

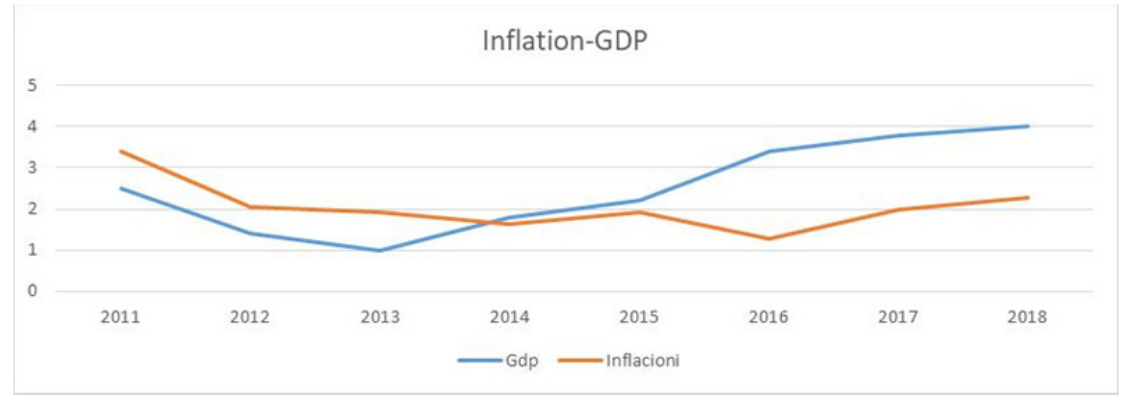

Figure 2: Inflation trend and GDP trend.

Data Source : The Bank of Albania 


\section{Journal of International Cooperation and Development}

www.richtmann.org/journal

Vol 2, No 2, November 2019

In the data a simple analysis was conducted taking in consideration only this two factors to see the relation between the inflation and GDP with the aim to check if there is a positive or negative relation between them.

The statistical analysis resulted in the following simple regression :

GDP $=0.04285 *$ INFLATION + 2.424 .

This model shows a positive relationship between the two variables that can be seen even on the graphic. When the inflation rate is going down, the GDP is also down and the same happens even when we have an increasing level of inflation. This model although, does not show the proper level of growth in the economy for a certain growth in the inflation level because there are also other factors that should be taken into consideration.

\section{Conclusion}

In conclusion, the literature review showed that there are many points of views regarding the effect of monetary policy in the economic growth of a country. There are many factors that influence the Bank of Albania to use certain monetary policy.

The inflation target of $3 \%$ indicates the goal of controlling price increases at a level close to that of the European Central Bank, which has an inflation target below level 2. The objective level enables achieving real convergence and a nominal value of the Albanian economy with other countries economies within the European Union in the medium term. The implementation of monetary policy is realized through a series of indirect monetary instruments such as the open market operations, permanent facilitations and obligatory reserves. The monetary policy in Albania is influenced by the use of the EUR currency at a high level and the time of monetary policy transmission.

Regarding the relation between the monetary policy, represented by the inflation rate and the economic growth, measured by the GDP, there is a connection between these two factors.

\section{References}

Gust, C. and López-Salido, D. (2014) 'Monetary policy and the cyclicality of risk', Journal of Monetary Economics. Elsevier, 62(1), pp. 59-75.

Friedman, B. M. (1988). Targets and instruments of monetary policy. Nber working paper series, (2668).

Friedman, M. (1968). The role of Monetary Policy. The American Economic Review, LVIII.

Stein, J. C., Barro, R., Benmelech, E., Caballero, R., Gertler, M., Goodfriend, M., ... Scharfstein, D. (2011). Monetary policy as financial-stability regulation. National bureau of economic research.

Woodford, M. (2002). Interest and Prices. In Princeton University.

Bindseil, Ulrich, Gonzalez, Fernando and Tabakis, Evangelos, (2009), Risk Management for Central Banks and Other Public Investors, Cambridge University Press, https://EconPapers.repec.org /RePEc:cup:cbooks:9780521518567. 


\section{Journal of International Cooperation and Development}

www.richtmann.org/journal

Vol 2, No 2, November 2019

Bank of Albania. Accessed at https://www.bankofalbania.org/Monetary_Policy/Monetary Implementation/

Constitution of the Republic of Albania, 1997. Bank of Albania . Accessed at https://www.bankofalbania.org/Rreth_Bankes/Legjislacioni/Ligj_nr_8269_date_23_12_1997_Pe r_Banken_e_Shqiperise.html 